\title{
Dams and the economic value of sediment in the Vietnamese Mekong Delta
}

\author{
Chapman, A.D ${ }^{1^{*}}$ \& Darby, S.E. ${ }^{1}$ \\ ${ }^{1 *}$ NEF Consulting, London, United Kingdom, adc506@gmail.com \\ ${ }^{2}$ Geography and Environment Department, University of Southampton, United Kingdom
}

Intralawan et al.'s (2018) recent paper in Ecosystem Services makes a significant contribution to the debate surrounding the extensive programme of hydropower dams proposed and under construction along the Mekong River and its tributaries. They concluded that the economic value of the ecosystem services which will be lost (fish, sediment/sediment-bound nutrients, social/cultural services) outweigh the value of those to be provided by the dams (electricity generation, irrigation, flood control). This will likely draw significant public attention. Given the significance of Intralawan et al.'s paper, here we provide a further commentary in relation specifically to their quantification of the economic value of fluvial sediment provided to the Vietnamese Mekong Delta (VMD). In advance, however, we note that their most significant finding, a Net Present Value (NPV) for the '11 dam' scenario of $-\$ 7.3$ billion, remains robust irrespective of the precise negative contribution from sediment, i.e. the overall NPV remains negative with or without the $-\$ 2.3$ billion contribution they estimate from sediment-bound nutrients.

Sediment provides a myriad of ecosystem services to societies in deltaic environments and throughout the river-to-sea continuum. The most fundamental of the deltaic services is (i) the provision of land; fluvial sediment, deposited on the delta floodplain, physically builds deltas, thereby providing a means to offset relative sea-level rise and reduce the risk of flooding (Syvitski and Kettner, 2011). Sediment starved rivers hold greater erosive capacity, pointing to a second sediment service (ii) that of river-form stabilisation and influence over river navigability; river bank erosion can threaten ecosystems as well as homes, lives and riparian infrastructure (Darby et al., 2013). Sediment-bound nutrients enhance the soil fertility and thus the productivity of delta ecosystems (iii) (Tsheboeng et al. ,2014; Edmonds, 2012), and when deposited on the floodplain, these nutrients provide a measurable boost to agricultural productivity (iv) (Chapman et al., 2016). The last of these services is the only one quantified by Intralawan et al. (2018), who estimate its value at $\$ 220$ million per year. This estimate is derived from a secondary source, specifically a study conducted by the consultancy firm DHI that was commissioned by the Ministry of Natural Resources and the Environment [MONRE]; Government of Vietnam (2015). 


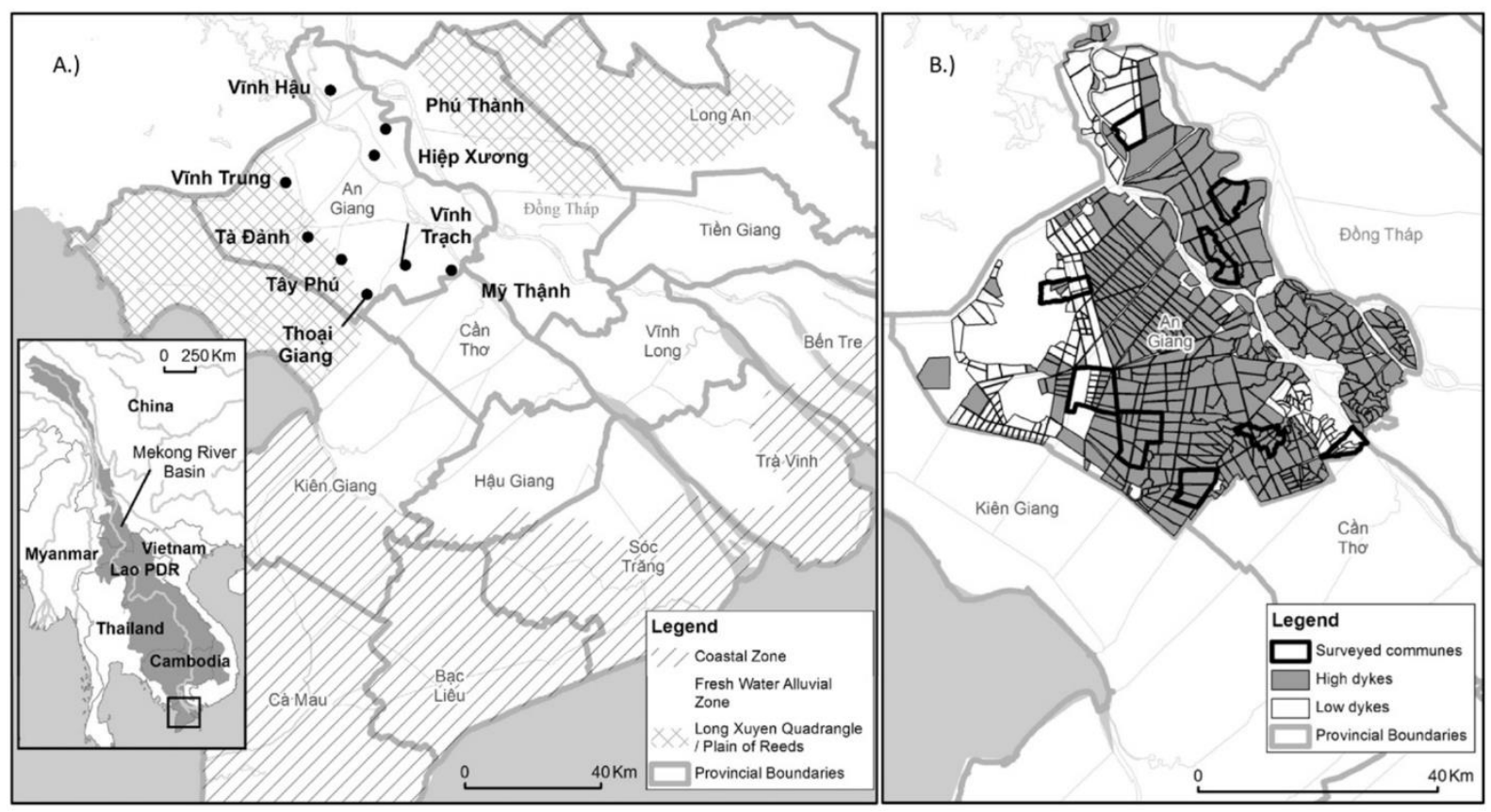

Figure 1 A.) The different (locally-recognised) ecological zones of the Vietnamese Mekong Deltaand B.) An Giang Province and its high and low dyke network (Chapman and Darby, 2016)

Our own research findings are comparable with the DHI estimate. In Chapman et al. (2016) we report on an empirical study of Vietnamese rice farmers from which we estimate that sedimentbound nutrients, deposited on rice paddies by the annual flood, have a potential economic value of $\$ 26( \pm 9)$ million per year within a single province, An Giang. This value is derived primarily from fertiliser savings. Given that all 13 provinces of the Mekong Delta have the potential to receive free sediment-bound nutrients, a total of $\$ 220$ million per year is possible; though the work of Manh et al. (2014) should be noted, they suggest that minimal sediment reaches the Delta provinces which are located in the coastal zone (see Figure 1). Given the unquantified additional ecosystem services listed above (i-iii), a potential annual value of $\$ 220$ million is very likely an underestimate. Our research has also shown that poorer households in the Delta will suffer most from the decrease in sediment service provision (Chapman and Darby, 2016).

However, what is not explicitly recognised in Intralawan et al.'s (2018) paper is that estimates of the delivery of sediment-bound nutrients to agricultural soils within the VMD are likely biased. An extensive network of dykes now effectively blocks the flood and associated sediment from the floodplain in much of the northern delta (see Figure 1). Thus the use of local infrastructure has a more significant control over sediment loads than the upstream catchment management practices such as damming (Kondolf et al., 2014) and climate change (Darby et al., 2016). Our research (Chapman et al., 2016; Chapman and Darby 2016) highlights that farmers are experiencing declining profit margins resulting from the loss of free nutrients bound to sediments that are deposited on their paddies in the event of flooding. Indeed, this loss may well be a contributing factor in the recent high net outmigration rates evident in An Giang Province (Figure 2); though a causal relationship is only loosely evidenced through our previous papers (Chapman et al., and Chapman and Darby, 2016) and further research is required. It should also be recognised that the dyke network itself provides significant benefits to farmers in that it helps prevent flooding damaging yields, and the exclusion of flood waters also allows farmers to grow a third rice-crop during the monsoon season. The additional revenue this generates, which effectively represents opportunity cost against sediment deposition, would be significant in any calculation of the realised rather than 
theoretical value of the loss of ecosystem services provision due to the proposed Mekong Dams. The model used in the government report cited by Intralawan et al. (2018) apparently does not take these issues into consideration when estimating the $\$ 220$ million annual value. The report (MONRE, 2015) makes reference only to a spreadsheet model which, to our knowledge, would not have had the capacity to simulate the dynamics and spatial relationships between dykes, dyke management, and sediment deposition in generating economic value in the Delta. Page 8 of the "Methods and Results" document does make the claim that dyke extent and topographic information were integrated into the model. But, when the agriculture impact assessment model is presented (pages 47 and 48) no mention is made of the implications of dike height, cropping patterns, and sluice gate operation on the extent of sediment deposition and hence nutrient availability, all of which are variables we know to be critical to determining the levels of ecosystem service provided.

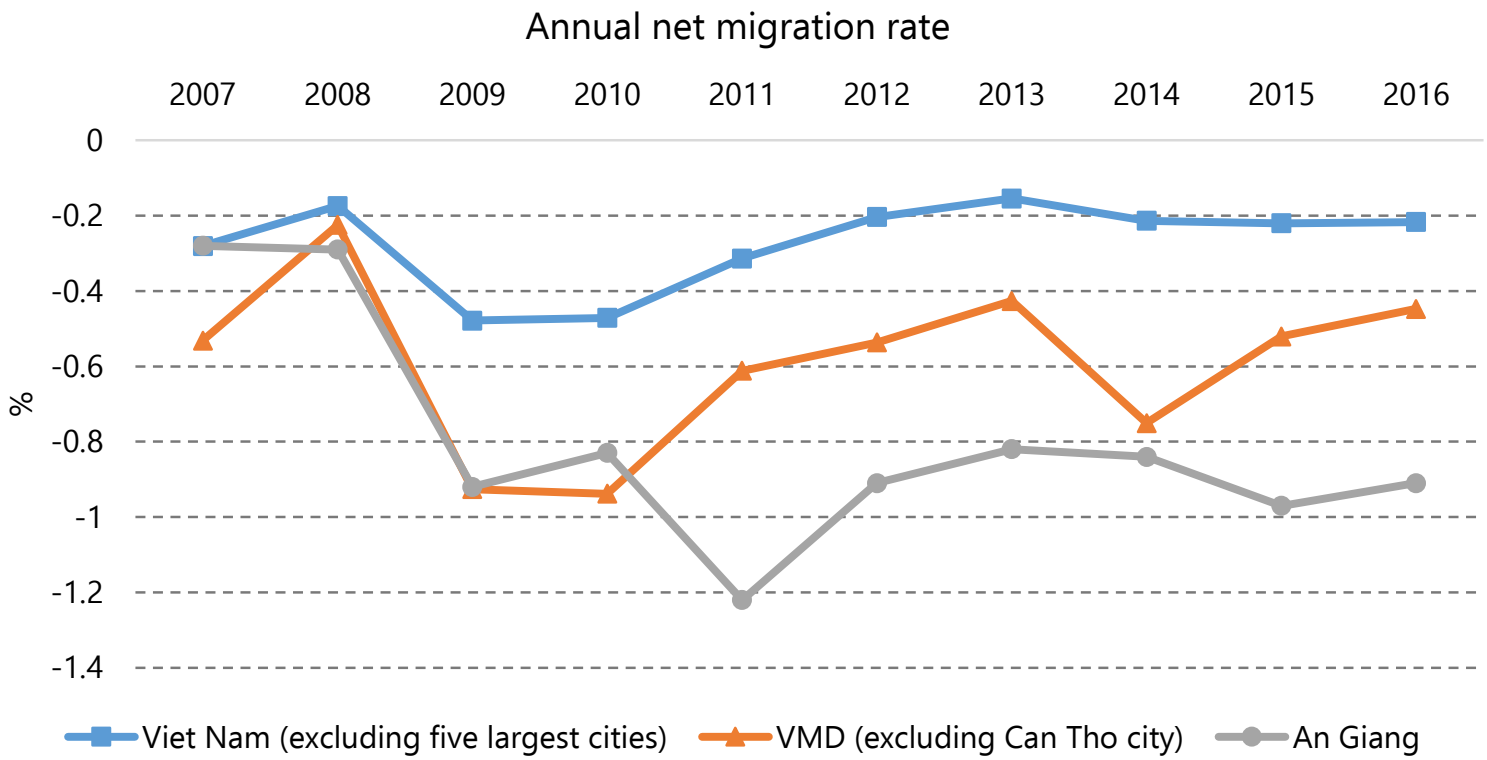

Figure 2 Government migration statistics for various regions of Vietnam; VMD - Vietnamese Mekong Delta (data collected from the General Statistics Office of Vietnam, available online at www.gso.gov.vn)

The issues discussed in this letter are of considerable significance to policy making in the VMD, as the Government forms plans for its future management under scenarios of rising sea-levels, and develops its position towards upstream damming. In this letter we highlight that while \$220 million per year is likely an underestimate of the potential total system-wide benefits of sediment related ecosystem services provision, the vast majority of the quantifiable economic value of Mekong River sediment in the delta is not well constrained. With likely irreversible decisions imminent, considerable further research is urgently required into the social-ecological dynamics of sediment within the VMD, as well as in other vulnerable river deltas, its sustainable management, and the impact of policies moving into the future.

\section{References}

Chapman, A., \& Darby, S. (2016). Evaluating sustainable adaptation strategies for vulnerable megadeltas using system dynamics modelling: Rice agriculture in the Mekong Delta's An Giang Province, Vietnam. Science of the Total Environment, 559, 326-338. 
Chapman, A. D., Darby, S. E., Hồng, H. M., Tompkins, E. L., \& Van, T. P. D. (2016). Adaptation and development trade-offs: fluvial sediment deposition and the sustainability of rice-cropping in An Giang Province, Mekong Delta. Climatic Change. http://doi.org/10.1007/s10584-016-1684-3

Darby, S. E., Leyland, J., Kummu, M., Rasanen, T., \& Lauri, H. (2013). Decoding the drivers of bank erosion on the Mekong River: the roles of the Asian monsoon, tropical storms and snow melt. Water Resources Research, 49(4), 2146-2163. DOI: 10.1002/wrcr.20205

Darby, S. E., Hackney, C. R., Leyland, J., Kummu, M., Lauri, H., Parsons, D. R., ... Aalto, R. (2016). Fluvial sediment supply to a mega-delta reduced by shifting tropical-cyclone activity. Nature, 539, 276. Retrieved from http://dx.doi.org/10.1038/nature19809

Edmonds, D. A. (2012). Restoration sedimentology. Nature Geoscience, 5(11), 758-759. http://doi.org/10.1038/ngeo1620

Intralawan, A., Wood, D., Frankel, R., Costanza, R., \& Kubiszewski, I. (2018). Tradeoff analysis between electricity generation and ecosystem services in the Lower Mekong Basin. Ecosystem Services, 30, 27-35. http://doi.org/10.1016/j.ecoser.2018.01.007

Kondolf, G. M., Rubin, Z. K., \& Minear, J. T. (2014). Dams on the Mekong: Cumulative sediment starvation. Water Resources Research, (50), 5158-5169.

http://doi.org/10.1002/2013WR014651.Received

Manh, N. V., Dung, N. V., Hung, N. N., Merz, B., \& Apel, H. (2014). Large-scale suspended sediment transport and sediment deposition in the Mekong Delta. Hydrology and Earth System Sciences, 18(8), 3033-3053. http://doi.org/10.5194/hess-18-3033-2014

Ministry of Natural Resources and the Environment (MONRE); Government of Vietnam. (2015). Study on the Impacts of Mainstream hydropower on the Mekong: Final Report.

Syvitski, J. P. M., \& Kettner, A. (2011). Sediment flux and the Anthropocene. Philosophical Transactions. Series A, Mathematical, Physical, and Engineering Sciences, 369(1938), 957-75. http://doi.org/10.1098/rsta.2010.0329

Tsheboeng, G., Bonyongo, M., \& Murray-Hudson, M. (2014). Flood variation and soil nutrient content in floodplain vegetation communities in the Okavango Delta. South African Journal of Science, 110(3/4), 1-5. http://doi.org/10.1590/sajs.2014/20130168 